\title{
PENGEMBANGAN MODEL PEMBELAJARAN KARAKTER BERBASIS SAINTIFIK DI SEKOLAH DASAR
}

\author{
Dra. Ina Marlina, M.Pd \\ STKIP Subang \\ marlina.ina@yahoo.com
}

\begin{abstract}
The purpose of this article is to develop the learning model based on scientific approach in the elementary school. The stages of scientific approach are in these models. Based on the nature of character itself, the character learning models can be divided into two kinds, namely reflective model and rational construction model. The development of education in elementary school has been orientating not only in cognitive aspect but also the value aspect that presents the character education in elementary school. The development of character education have to appropriate with the identity of that character education. Having the comprehension of character learning model, the teachers will reach the purpose as well as to solve the problems especially in education nowadays.
\end{abstract}

Keywords: scientific approach,development model of character, model reflectif, and model development.

\section{ABSTRAK}

Tujuan artikel ini adalah untuk mengembangkan model pembelajaran berdasarkan pendekatan ilmiah di sekolah dasar. Tahapan pendekatan ilmiah dalam model ini. Berdasarkan sifat karakter itu sendiri, karakter model pembelajaran dapat dibagi menjadi dua macam, yaitu model yang reflektif dan model pembangunan yang rasional. Pengembangan pendidikan di sekolah dasar telah orientating tidak hanya dalam aspek kognitif, tetapi juga aspek nilai yang menyajikan pendidikan karakter di sekolah dasar. Pengembangan pendidikan karakter harus yang sesuai dengan identitas bahwa pendidikan karakter. Memiliki pemahaman model pembelajaran karakter, guru akan mencapai tujuan serta untuk memecahkan masalah terutama dalam pendidikan saat ini.

Kata kunci: pendekatan ilmiah, model pengembangan karakter, Model reflectif, dan pengembangan model.

\section{PENDAHULUAN}

Munculnya berbagai persoalan sosial di kalangan siswa seperti narkoba, pornografi, penipuan, penganiyaan, perjudian, tawuran pelajar bahkan pembunuhan yang terjadi sekarang ini mengindikasikan bahwa karakter bangsa Indonesia telah luntur. Berdasarkan persoalanpersoalan tersebut, pendidikan karakter menjadi kebutuhan mendesak mengingat demolarisasi dan degradasi pengetahuan sudah sedemikian akut menjangkiti bangsa ini di semua lapisan masyarakat. Pendidikan karakter diharapkan mampu membangkitkan kesadaran bangsa ini untuk membangun pondasi kebangsaan yang kokoh (Asmani, 2011). Dengan demikian, urgensi pendidikan karakter merupakan bagian dari tujuan bangsa Indonesia, 
yakni sebagai bangsa yang cerdas baik segi intelektual maupun spiritual, mampu membangun peradaban bangsa yang kuat dan sejahtera, dan mampu mencetak kader bangsa yang potensial.

Hal ini sesuai dengan tujuan pendidikan sebagaimana pasal 3 UU No 20/2003 tentang Sistem Pendidikan Nasional, yaitu "mengembangkan kemampuankemampuan dan membentuk watak serta peradaban bangsa yang bermartabat dalam rangka mencerdaskan kehidupan bangsa, bertujuan mengembangkan potensi peserta didik agar menjadi manusia yang beriman dan bertaqwa kepada Tuhan Yang Maha Esa, berakhlak mulia, sehat, berilmu, cakap, kreatif, mandiri, dan menjadi warga Negara yang demokratis serta bertanggung jawab."

Agar tujuan yang dicita-citakan diatas terlaksana hendaknya para guru mengetahui sebuah model pembelajaran karena mengingat pendidikan karakter ini bukan tugas guru satu bidang studi saja seperti guru mata pelajaran agama ataupun PKn, akan tetapi merupakan tugas semua guru mata pelajaran di sekolah baik guru bahasa, IPS, IPA dan lainlain. Menurut Muhibbin Syah (2007), penyusunan metode maupun model disajikan sesuai dengan relevansi dengan kebutuhan dunia pendidikan saat ini. Mengingat urgensi pendidikan karakter yang ada, maka perlunya sebuah pengembangan model pembelajaran karakter berbasis saintifik.

Ada dua macam model pembelajaran karakter berbasis saintifik, yaitu model reflektif dan model pembangunan rasional (Darma Kusuma, dkk.,2012). Kedua model ini dikatakan berdasarkan saintifik dikarenakan langkah-langkah dan esensi pendekatan saintifik terdapat dalam kedua model tersebut. Kedua model tersebut akan dibahas secara ringkas sesudah mengulas tentang karakteristik model pembelajaran, esensi pendekatan ilmiah, pendekatan ilmiah, langkah-langkah pendekatan ilmiah, klasifikasi model-model pembelajaran dan klasifikasi pembelajaran dalam pendidikan karakter.

\section{KARAKTERISTIK PEMBELAJARAN}

MODEL

Dalam proses pembelajaran tentunya harus memiliki sebuah rencana. Rencana tersebut memuat berbagai langkah-langkah yang sistematis dan logis. Langkah tersebut memberikan sebuah jalan untuk mencapai tujuan yang diinginkan. Hal ini selaras dengan apa yang dikatakan Muhibbin Syah (2007) tentang modelmodel pembelajaran. Dia mengatakan bahwa model pembelajaran adalah blue print mengajar yang direkayasa sedemikian rupa untuk mencapaian tujuan-tujuan tertentu pengajaran. Cetak biru ini lazimnya dijadikan pedoman perencanaan dan pelaksanaan serta evaluasi belajar. Selain itu menurutnya dalam model pembelajaran biasanya terdapat tahapan-tahapan atau sintak yang relatif tetap dan pasti untuk menyajikan materi pelajaran secara berurutan. Oleh karena itu, sebuah model mengajar dapat dianggap sebagai teori mini yang bersifat mekanis dalam arti berjalan secara tetap seperti mesin.

Menurut Arens (dalam Insih, 2009) model pembelajaran mempunyai makna yang lebih luas daripada suatu strategi, metode, atau prosedur. Istilah model pembelajaran adalah pendekatan tertentu dalam 
pembelajaran yang tercakup dalam tujuan, sintak, lingkungan dan sistem manajemen agar konsep model tersebut jelas perbedaannya, maka harus ditarik benang merah yang membedakan model dengan strategi.

Salah satu cara untuk mengetahui model pembelajaran yaitu dengan mengetahui karakteristik atau ciri dari model tersebut. Model pembelajaran menurut Ali memiliki ciri-ciri sebagai berikut:

a. Berdasarkan teori pendidikan dan teori belajar dari para ahli tertentu.

Sebagai contoh, model penelitian kelompok disusun oleh Herbert Thelen dan berdasarkan teori John Dewey. Model ini dirancang untuk melatih partisipasi dalam kelompok secara demokratis.

b. Mempunyai misi atau tujuan pendidikan tertentu.

Misalnya model berpikir induktif dirancang untuk mengembangkan proses berpikir induktif.

c. Dapat dijadikan pedoman untuk perbaikan kegiatan belajar mengajar di kelas. Misalnya model synectic dirancang untuk memperbaiki kreativitas dalam pelajaran mengarang.

Memiliki bagian-bagian model yang dinamakan: (1) urutan langkahlangkah pembelajaran (syntax), (2) adanya prinsip-prinsip reaksi, (3) sistem sosial, dan (4) sistem pendukung. Keempat bagian tersebut merupakan pedoman praktis bila guru akan melaksanakan suatu model pembelajaran.

d. Memiliki dampak sebagai akibat terapan model pembelajaran.

Dampak tersebut meliputi: dampak pembelajaran, yaitu hasil belajar yang dapat diukur (2) dampak pengiring, yaitu hasil belajar jangka panjang. e. Membuat persiapan mengajar (desain instruksional) dengan pedoman model pembelajaran yang dipilihnya.

\section{KLASIFIKASI PEMBELAJARAN}

MODEL-MODEL

Menurut Tardif (dalam Muhibbin, 2007) menyatakan bahwa kumpulan atau set model mengajar yang dianggap komprehensif adalah set model yang dikembangkan oleh Bruce Joyce dan Marsha Weil dengan kategorisasi sebagai berikut:

a. Model information Processing

Information Processing adalah sebuah istilah kunci dalam psikologi kognitif yang akhir-akhir ini semakin mendominasi sebagian besar upaya riset dan pembahasan psikologi pendidikan. Kata information processing sesungguhnya dipinjam dari peristilahan komputer untuk menjelaskan aktifitas mental (dalam hal ini mental siswa) ketika mengoperasikan pengetahuan dan mengolah informasi yang diekstraksikan dari peristiwaperistiwa yang ada dilingkungan sekitarnya, seperti suara atau kata, gerakan benda, gambar, dan sebagainya.

b. Model personal

Rumpun model personal pada umumnya berorientasi pada pengembangan pribadi siswa dengan lebih banyak memperhatikan kehidupan ranah rasa, terutama fungsi emosionalnya. Bantuan rumpun model personal lebih ditekankan pada pembentukan dan pengorganisasian realitas kehidupan lingkungan dan kehidupan yang unik. Diharapkan, dengan menggunakan model ini 


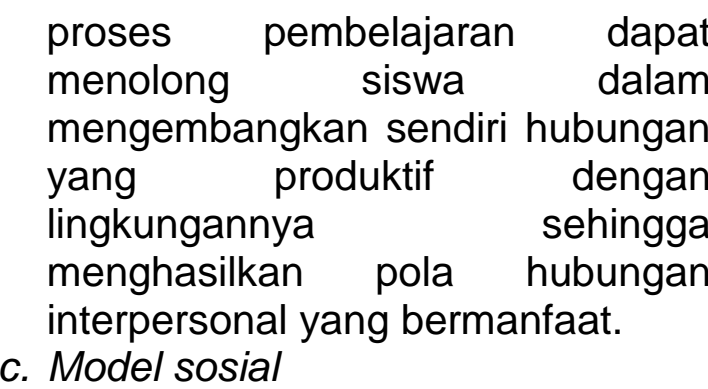

Model sosial adalah rumpun model mengajar yang menitikberatkan pada proses interaksi antarindividu yang terjadi dalam kelompok individu tersebut. Oleh karenanya, rumpun model ini lazim juga disebut sebagai interactive model (model yang bersifat antarindividu). Aplikasi rumpun model ini diprioritaskan untuk mengembangkan kecakapan individu siswa dalam berhubungan dengan orang lain atau masyarakat sekitarnya.

d. Model behavioral

Rumpun model mengajar ini direkayasa atas dasar kerangka teori perilaku yang dihubungkan dengan proses belajar dan mengajar. Aktivitas belajar menurut teori ini, harus ditujukan pada timbulnya perilaku baru atau berubahnya perilaku siswa kearah yang diharapkan.

Dari keempat model tersebut menghasilkan sebuah penurunan model-model seperti model peningkatan kapasitas berpikir pada model information processing, model nondirectiktif pada model personal, model role playing pada model sosial, model mastery learning pada model behavioral.

\section{ESENSI PENDEKATAN ILMIAH}

Pembelajaran merupakan proses ilmiah. Karena itu Kurikulum 2013 mengamanatkan esensi pendekatan ilmiah dalam pembelajaran. Pendekatan ilmiah diyakini sebagai titian emas perkembangan dan pengembangan sikap, keterampilan, dan pengetahuan peserta didik. Dalam pendekatan atau proses kerja yang memenuhi kriteria ilmiah, para ilmuan lebih mengedepankan pelararan induktif (inductive reasoning) ketimbang penalaran deduktif (deductive reasoning).

\section{PENDEKATAN ILMIAH}

Proses pembelajaran harus dipandu dengan kaida-kaidah pendekatan ilmiah. Pendekatan ini bercirikan penonjolan dimensi pengamatan, penalaran, penemuan, pengabsahan, dan penjelasan tentang suatu kebenaran. Dengan demikian, proses pembelajaran harus dilaksanakan dengan dipandu nilainilai, prinsip-prinsip, atau kriteria ilmiah. Proses pembelajaran disebut ilmiah jika memenuhi kriteria seperti berikut ini.

1. Substansi atau materi pembelajaran berbasis pada fakta atau fenomena yang dapat dijelaskan dengan logika atau penalaran tertentu; bukan sebatas kira-kira, khayalan, legenda, atau dongeng semata.

2. Penjelasan guru, respon peserta didik, dan interaksi edukatif gurupeserta didik terbebas dari prasangka yang serta-merta, pemikiran subjektif, atau penalaran yang menyimpang dari alur berpikir logis.

3. Mendorong dan menginspirasi peserta didik berpikir secara kritis, analistis, dan tepat dalam mengidentifikasi, memahami, memecahkan masalah, dan mengaplikasikan substansi atau materi pembelajaran.

4. Mendorong dan menginspirasi peserta didik mampu berpikir hipotetik dalam melihat perbedaan, 
kesamaan, dan tautan satu sama lain dari substansi atau materi pembelajaran.

5. Mendorong dan menginspirasi peserta didik mampu memahami, menerapkan, dan mengembangkan pola berpikir yang rasional dan objektif dalam merespon substansi atau materi pembelajaran.

6. Berbasis pada konsep, teori, dan fakta empiris yang dapat dipertanggungjawabkan.

7. Tujuan pembelajaran dirumuskan secara sederhana dan jelas, namun menarik sistem penyajiannya.

\section{LANGKAH-LANGKAH PENDEKATAN ILMIAH}

Kurikulum 2013 menekankan pada dimensi pedagogik modern dalam pembelajaran, yaitu menggunakan pendekatan ilmiah. Pendekatan ilmiah (scientific appoach) dalam pembelajaran sebagaimana dimaksud meliputi mengamati, menanya, mencoba, mengolah, menyajikan, menyimpulkan, dan mencipta untuk semua mata pelajaran.

Untuk mata pelajaran, materi, atau situasi tertentu, sangat mungkin pendekatan ilmiah ini tidak selalu tepat diaplikasikan secara prosedural. Pada kondisi seperti ini, tentu saja proses pembelajaran harus tetap menerapkan nilai-nilai atau sifat-sifat ilmiah dan menghindari nilai-nilai atau sifat-sifat nonilmiah. Pendekatan ilmiah pembelajaran disajikan berikut ini. (Kurikulum, 2013)

\section{KLASIFIKASI PEMBELAJARAN DALAM PENDIDIKAN KARAKTER}

Pusat Pengkajian Pedagogik UPI (Darma, dkk., 2012) sebagai salah satu institusi yang mencoba mengembangkan teori dan praktik pendidikan dalam pendidikan karakter membagi dua bentuk pembelajran dalam pendidikan karakter, yaitu:

a. Pembelajaran substantif.

Pembelajaran substantif adalah pembelajaran yang substansi materinya terkait langsung dengan suatu nilai. Seperti pada mata pelajaran agama dan PPKn. Proses pembelajaran substantif dilakukan dengan mengkaji suatu nilai yang dibahas, mengkaitkannya dengan kemaslahatan kehidupan anak dan kehidupan manusia, baik di dunia maupun diakhirat. Proses pembelajaran selalu dikaitkan dengan nilai yang ingin diperkuat pada anak. Misal nilai yang terkandung dalam shalat adalah penghambaan, ketertiban, kerendahan hati, keikhlasan, kebersamaan, dan sebagainya. Nilai mana yang akan dirujuk dalam pembelajaran terlebih dahulu didesain oleh guru atau kelompok guru mata pelajaran yang mengarah pada visi sekolah. Demikian halnya dengan mata pelajaran pendidikan kewarganegaraan.

b. Pembelajaran reflektif.

Pembelajaran reflektif adalah pendidikan karakter yang terintegrasi pada semua mata pelajaran disemua jenjang dan jenis pendidikan. Proses pembelajaran dilakukan oleh semua guru mata pelajaran atau bidang studi, seperti guru Matematika, IPS, IPA, Bahasa Indonesia, dan lainnya. Proses pembelajaran reflektif dilakukan melalui pengaitan materi-materi yang dibahas dalam pembelajaran dengan makna di belakang materi tersebut. Ketika materi suatu pembelajaran direflesikan kedalam kehidupan manusia, maka ada nilai yang dapat dikuatkan bagi anak, 
seperti nilai saling menghormati terhadap perbedaan ataupun nilai lain. Jadi, materi yang dibahas guru dikelas intinya selalu direflesikan terhadap sebuah nilai dibalik materi dan kemudian dikaitkan dengan kemaslahatan kehidupan anak.

Dari kedua klasifikasi pembelajaran karakter tersebut, penulis mengangkat dua macam model pembelajaran karakter berbasis saintifik, yaitu model reflektif dan model pembanguanan rasional. Kedua model tersebut mampu berintegrasi baik kepada mata pelajaran yang sifat substantif maupun reflektif yang telah dipaparkan diatas.

\section{PENGEMBANGAN PENDIDIKAN BERBASIS MODEL REFLEKTIF}

Adapun acuan kerangka sistematis yang memperkuat pengembangan pendidikan dalam model ini mecakup (a) asumsi dasar model reflektif, (b) prinsip-prinsip pembelajaran model reflektif, (c) proses pembelajaran model reflektif, (d) evaluasi dalam model reflektif. Keempat hal tersebut dipaparkan berikut ini (Kusuma,dkk., 2012).

\section{Asumsi Dasar Model Reflektif}

Anak (peserta didik) adalah individu manusia yang memiliki kemampuan untuk melihat jauh ke belakang dan menerawang suatu kondisi ke masa depan yang diinginkan. Kemudian manusia pada dasarnya memiliki kata hati/nurani yang Allah berikan. Dengan asumsi inilah maka kehidupan manusia tidak akan pernah lepas dari proses refleksi. Ketika manusia dilahirkan ke dunia dan mulai berkembang kemampuan berpikirnya, akan muncul pertanyaan dalam dirinya, untuk apa ia lahir atau untuk apa ia hidup di dunia? Pertanyaan tersebut menunjukkan bahwa manusia akan selalu berpikir mengenai kondisi spiritual di balik keduniaan.

Refleksi merupakan proses seseorang untuk memahami makna dibalik suatu fakta, fenomena, informasi, atau benda. Model reflektif dalam bagian ini adalah model pembelajaran pendidikan karakter yang diarahkan pada pemahaman terhadap makna dan nilai yang terkandung di balik teori, fakta, fenomena, informasi, atau benda yang menjadi bahan ajar dalam suatu mata pelajaran. Pembelajaran reflektif bertujuan untuk menguatkan dan mengembangkan nilai-nilai yang akan diperkuat melalui pembelajaran pada berbagai mata pelajaran yang secara substansi tidak terkait langsung dengan nilai sampai pada level paling atas, yaitu mengajak orang-orang di lingkungan untuk mempraktikkan nilai yang dipelajarinya dalam kehidupan keseharian.

\section{Prinsip-prinsip Pembelajaran Model Reflektif}

Prinsip pembelajaran adalah dasar atau asas yang dijadikan landasan dalam melaksanakan pembelajaran. Prinsip pembelajaran model reflektif di bangun berdasarkan pada pemikiran tentang hakikat berpikir. Prinsip-prinsip yang harus ditempuh untuk mengimplementasikan pembelajaran reflektif adalah sebagai berikut.

a. Dasar interaksi pembelajaran antara guru dan peserta didik adalah kasih sayang. Kasih sayang merupakan dasar awal yang harus ditumbuhkan pada guru dan anak ketika akan melangsungkan proses pembelajaran.

b. Sikap dan perilaku guru harus mencerminkan nilai yang dianut 
atau dirujuk oleh sekolah. Dasar interaksi yang kedua adalah keteladanan guru. Barangkali landasan ini perlu untuk diperkuat semenjak seseorang menjalani proses kuliah sebagai pendidik di LPTK.

c. Pandangan guru terhadap peserta didik adalah subjek yang sedang tumbuh dan berkembang yang pertumbuhan

dan

perkembangannya terkait dengan guru. Guru perlu merasa apapun yang dilakukan dalam KBM memiliki pengaruh kuat terhadap tumbuh kembangnya perilaku anak.

\section{Proses Pembelajaran Model Reflektif}

Proses pembelajaran model reflektif dilakukan oleh semua guru mata pelajaran melalui integrasi materi-materi disetiap mata pelajaran dengan nilai-nilai tertentu yang akan diperkuat menjadi sikap anak. Pelaksanaan pembelajaran reflektif dapat terjadi pada setiap tahap dari tahapan proses pembelajaran. Misal ketika guru membiasakan untuk menyapa anak sebelum pembelajaran dimulai, secara reflektif guru tersebut membelajarkan nilai keramahan kepada peserta didik. Tahapan yang harus dilakukan guru untuk melaksanakan pembelajaran reflektif sebagai berikut.

a. Menyusun RPP berbasis karakter.

b. Guru melakukan apersepsi yang kontekstual dengan kehidupan anak dan terkait dengan materi yang akan dibahas. Apersepsi yang lebih tepat dilakukan dengan memfokuskan pikiran dan konsentrasi anak untuk siap memasuki kajian lebih mendalam.

c. Melakukan pembelajaran sebagaimana didesain dalam RPP. Dalam pelaksanaan kegiatan inti pembelajaran, guru melakukan elaborasi terhadap berbagai makna dari materi yang dibahas.

d. Melakukan evaluasi yang dilakukan melalui pengamatan terhadap sejauhmana nilai-nilai yang akan dikuatkan atau dikembangkan muncul dalam perilaku anak.

e. Memberikan catatan khusus (anekdot) jika ada anak yang secara khusus memiliki perkembangan perilaku yang berbeda dengan kelompoknya, apahkah bersifat positif atau negatif. Sebaiknya catatan anekdot dibukukan dalam bentuk buku penghubung atau buku harian anak.

f. Memberikan referensi kepada guru lain, apahkah guru BP atau wali kelas, orang tua, atau berbagai pihak yang berkepentingan yang dianggap layak untuk menangani anak-anak yang dikategorikan memiliki kekhususan dalam perkembangan nilai dan karakter.

\section{Evaluasi dalam Pembelajaran Model Reflektif}

Evaluasi pembelajaran reflektif adalah evaluasi yang ditujukan untuk melihat sejauhmana berbagai karakter dan nilai yang dikembangkan dapat dimiliki oleh anak. Evaluasi ini dilakukan melalui observasi terhadap perilaku anak. Observasi dilakukan melalui lisan, perbuatan, raut muka, gerak badan, dan berbagai hal lainnya.

\section{PENGEMBANGAN PENDIDIKAN BERBASIS MODEL PEMBANGU- NAN RASIONAL}

Tidak jauh berbeda seperti yang diuraikan pada model reflektif, model pembangunan rasionalpun memiliki empat acuan kerangka sistematis, yaitu (a) asumsi dasar model 
pembangunan rasional, (b) prinsipprinsip pembelajaran model pembangunan rasional, (c) proses pembelajaran model pembangunan rasional, (d) evaluasi dalam model pembangunan rasional. Keempat hal tersebut dipaparkan berikut ini.

\section{Asumsi Dasar Model Pembangunan Rasional (MPR)}

Pada hakikatnya manusia memiliki kelebihan dibandingkan dengan makhluk Tuhan lainnya, salah satunya karena manusia dianugeragi akal pikiran. Dengan asumsi tersebut, maka akal pikiran memiliki tugas yang cukup berat untuk memberikan pertimbangan dalam mengambil keputusan. Kelogisan dan kerasionalan menjadi sebuah ukuran penting untuk menghasilkan keputusan seseorang.Model pembangunan rasional (MPR) dinamai demikian karena fokus utama pembelajaran adalah kompetensi pembangunan rasional, argumentasi, atau alasan atas pilihan nilai yang dibuat anak.

Khusus untuk anak SD karena masih tahap operasional konkret, maka perlu kepandaian guru untuk menerawang proses berpikir anak. Kemana arah berpikirnya? Apahkah menyalahi nilai atau konsisten dengan nilai yang dianutnya.

\section{Prinsip-prinsip Pembelajaran Model} Pembangunan Rasional

Beberapa prinsip dari model ini, yaitu:

a. Logis, berarti dapat dipahami. Artinya proses pengembangan rasional anak harus dibawa kepada tahapan kemampuan berpikir anak yang dapat dipahami anak.

b. Rasional, berarti masuk akal. Dalam konteks pembangunan rasional anak didik perlu diajak memahami suatu perkara dari sisi rasionalitas. c. Sistematis, berarti bahwa pengembangan rasional anak harus dibawa untuk berpikir sistematis, sehingga memudahkan untuk berpikir memecahkan suatu maslah.

d. Sistemik, berarti pengembangan rasionalitas berpikir anak harus dibawa pada berpikir secara menyeluruh, tidak parsial. Dalam hal ini anak SD nantinya jadi antipator yang handal.

\section{Proses Pembelajaran Model Pembangunan Rasional}

Proses pembangunan rasional dilakukan dengan memperhatikan proses sebagaimana dikemukakan oleh Shever (dalam Darma, dkk., 2012:125-135), yaitu:

a. Identifikasi nilai dan klarifikasi nilai. Asumsi yang dikemukakan Shaver (dalam Darma Kusuma: 2012) bahwa "nilai akan membantu membentuk perilaku." Proses ini adalah proses kognitif, yakni proses individu berupaya menemukan dan memahami nilai-nilai yang berada di luar dirinya.

b. Generalisasi Label. Asumsinya adalah bahwa anak itu hidup ditengah masyarakat yang terbangun oleh sebuah system nilai tertentu, misalnya nilai-nilai demokrasi dan nilai-nilai religius.

c. Analisis Konflik nilai. Asumsinya bahwa putusan-putusan moral melibatkan konflik antar nilai. Proses ini dilakukan dengan mengkaji konsekuensi-konsekuensi dari sebuah perbuatan atas sebuah nilai moral, sehingga anak menemukan cita moral yang dikompromikan. Misal, anak ingin menolong orang lain yang kelaparan sementara dia sendiri memiliki uang yang jumlahnya hanya cukup untuk ongkos adalah 
situasi konflik. Ketika para siswa menilai implikasi-implikasi, konsekuensi-konsekuensi yang mungkin, dari putusan moral mereka, mereka perlu memandang konsep moral sebagai konstruk yang dimensional ketimbang kategoris.

d. Pengambilan putusan. Asumsinya bahwa sebuah nilai dapat menjadi prioritas bagi individu tertentu dan tidak menjadi prioritas bagi individu lainnya. Misal, mana yang harus dilakukan anak antara menolong orang kelaparan dengan pulang jalan kaki. Pada akhir situasi, anak harus membuat putusan yang mana putusan tersebut dipengaruhi mana prioritas nilai yang dimiliki anak.

Adapun sebuah contoh proses pembelajaran dengan menggunakan model pembangunan rasional sebagai berikut.

Pada suatu hari guru merasa kebingungan untuk mencapai suatu kondisi dimana anak-anak menjadi terbiasa melakukan shalat wajib. Proses pembelajaran dilakukan dengan cara anak membangun secara rasional mengenai "mengapa shalat itu diperlukan bagi manusia?" untuk mendapatkan jawaban ini, anak-anak diminta untuk melakukan observasi dan wawancara kepada orang yang shalat dan dinilai oleh anak itu shalatnya bermakna (orang tersebut merasa butuh). Dalam proses kegiatan belajarnya, guru bertanya, misal "nah anak-anak kita sudah belajar tentang bagaimana shalat (bacaan dan gerakannya), sekarang kita coba mempelajari mengapa shalat itu diperlukan oleh orang muslim. Pada saat itu banyak anak yang memiliki pandangan yang sama yaitu untuk membersihkan dosa selama lima kali sehari.
Hal ini belum membangun rasional mendalam. Kemudian guru, setelah elaborasi tersebut guru bertanya "apahkah ada di antara kalian yang pernah melihat orang yang shalat sambil menangis?" beberapa anak menjawab pernah. Kemudian guru meminta pendapat yang pernah melihat orang shalat sambil menangis tersebut. guru mengajak berpikir rasional anak, kirakira mengapa orang shalat sambil menangis. Apahkah karena sedang dirundung musibah? apahkah sedang menikmati pengakuan dosa dan meminta ampunan? apahkah dia merasakan bahwa dirinya sedang komunikasi dengan Allah SWT?

Diakhir pembelajaan guru memberikan tugas pada siswa untuk melakukan tindakan yang diungkap diatas yaitu observasi dan wawancara kepada orang terdekat mengenai pengalaman mereka dalam menjalankan shalat.

\section{Evaluasi dalam Pembelajaran Model Pembangunan Rasional}

Evaluasi dalam model pembangunan rasional pada akhirnya ditujukan untuk mengetahui tingkat ketepatan dan kebenaran putusan yang dibuat oleh anak. Penggunaan MPR dalam pendidikan nilai membuat pengajaran yang bersifat kognitif. Evaluasi dalam MPR berupa evaluasi kinerja siswa dalam mempertanggungjawabkan nilai-nilai yang dianut atau harus dianutnya.Alasan-alasan yang muncul ketika anak mengemukakan suatu gagasan, kritik, sanggahan merupakan komponen yang menjadi penilaian proses.

Sedangkan penilaian akhir dilakukan melalui evaluasi kinerja siswa. Kinerja siswa dapat tampak dalam situasi diskusi, atau dalam 
bentuk karya tulis yang dibuat siswa yang kemudian didiskusikan dengan teman-temannya di bawah bimbingan guru. Bentuk evaluasi lainnya adalah melalui tes kognitif.

\section{KESIMPULAN}

Model pembelajaran merupakan sebuah langkah sistematis untuk mencapai tujuan pembelajaran yang diinginkan. Berdasarkan pada pendidikan karakter, model pembelajaran karakter berbasis saintifik terbagi menjadi dua macam, yaitu model pembelajaran reflektif dan model pembangunan rasional. Kedua model ini mampu diaplikasikan pada mata pelajaran yang bersifat substantive seperti PPKn dan Agama serta mata pelajaran yang bersifat reflektif seperti kalau di SD yaitu bahasa Indonesia, Matematika, IPA, IPS, dan lainnya. Pemahaman terhadap model pembelajaran karakter dalam pendidikan di SD mampu mempermudah mencapai tujuan serta menjawab terhadap permasalahan yang terjadi sekarang ini.

\section{SARAN}

Dua model pengembangan karakter berbasis saintifik diatas kiranya dapat diterapkan oleh para guru di sekolah-sekolah dasar supaya mampu mencetak generasi bangsa yang memiliki kualitas yang baik dari segi intelektual, emosional dan spiritual yang pada akhirnya mampu menjawab dekadensi moral khususnya yang terjadi di abad sekarang ini.

\section{DAFTAR RUJUKAN}

Ali, Mohammad. (2007). Teori dan Praktik Pembelajaran di SD. Bandung: Pasca Sarjana UPI Bandung

Insih, Wilujeng. (2009). Model-model Pembelajaran Inovatif dan Kreatif dalam Pembeljaran Sains. Makalah disampaikan dalam rangka Pelatihan dan Workshop Pembelajaran Inovatif dan PTK guru-guru Sains di kabupaten Ngawi, Pendidikan Matematika UNY

Kementrian Pendidikan Nasional. (2010). Draft Induk Pendidikan Karakter.

Kesuma, Darma, Triatna, Permana. (2012). Pendidikan Karakter: Kajian Teori dan Praktik di Sekolah. Bandung: Rosda

Ma'mur, Jamal Asmani. (2011). Buku Panduan Internalisasi Pendidikan Karakter di Sekolah. Jogjakarta: Diva Press

Materi Diklat Kurikulum LPMP JABAR 2013.

Syah, Muhibbin. (2007). Psikologi Pendidikan dengan Pendekatan Baru.Bandung: Rosda

Syarif, Ahmad. (2013). Pembelajaran Karakter. Makalah pada diskusi pembelajaran Kajian Teori dan Praktik Pembelajaran, Pasca Sarjana UPI Bandung 